\title{
GEOSPATIAL DATA FOR ENERGY EFFICIENCY AND LOW CARBON CITIES - OVERVIEW, EXPERIENCES AND NEW PERSPECTIVES -
}

\author{
A. Nowacka ${ }^{1,2}$, F. Remondino ${ }^{3, *}$ \\ ${ }^{1}$ European Grouping of Territorial Cooperation NOVUM Limited, Jelenia Góra, Poland - \\ Email: anna.nowacka@euwt-novum.eu \\ ${ }^{2}$ Poltegor Institute, Opencast Mining Institute, Wrocław, Poland \\ ${ }^{3}$ 3D Optical Metrology (3DOM) unit, Bruno Kessler Foundation (FBK), Trento, Italy - Email: remondino@fbk.eu
}

Commission IV, WG IV/10

KEY WORDS: GIS, energy efficiency, light pollution, spatial planning, geodatabase, 3D city modeling

\begin{abstract}
:
The use of Geographic Information Systems (GIS) and their integration with 3D city models have become a common and powerful asset of cities for planning, visualization and decision-making operations in the fields of energy management, energy efficiency as well as transportation, public infrastructures, etc. The use of such solutions in urban spaces is still confined and mainly applied to visualization purposes (e.g. Google Earth) although geodata and spatial analyses can solve many problems towards the creation of smart cities. This paper presents an overview of various activities using spatial and non-spatial energy-related data integrated with 3D city models into GIS environments. It reviews existing solutions and reports two ongoing projects which deal with geospatial data for better planning and management of energy efficient public lighting and almost zero-consumption public buildings.
\end{abstract}

\section{INTRODUCTION}

Cities occupy some $2 \%$ of the earth's surface but their inhabitants consume approximately $75 \%$ of the world's energy resources (Gago et al., 2013). Most of the countries in the world are aiming at increasing the use of renewable energies and improving energy efficiency in cities and rural areas while exploiting the economic growth potential of the low-carbon sector. Various European Directives, including the Energy Efficiency Directive 2012/27/EU (2012), emphasize that big effort must be made by all Member States to optimize the use of energy sources. EU is aiming for a $27 \%$ cut in Europe's annual primary energy consumption by 2030 . This can be achieved in various ways, such as efficient implementation of energy efficiency plans, reduction of greenhouse gas (GHG) emissions, raising the production and consumption of renewable resources, etc. Some measures to reduce the energy consumption focus particularly on the building sector, as buildings alone consume some $40 \%$ of the total energy, of which about $68 \%$ is used by households, mainly for space heating, cooling, domestic hot water preparation, cooking and appliances (Skarbal et al., 2017). In most of the countries, large attention is being paid to improve energy efficiency of existing buildings or public streets, as they are accountable for large electric power consumption as well as night light pollution (Butt, 2012; Ruparathna et al., 2016). Urban lighting infrastructures (predominantly streets) are also a major source of energy consumption, accounting for some $2.3 \%$ of the global electricity consumption (Lobão et al., 2015), notwithstanding the indirect problems on citizens and animals for the caused night light pollution.

A rapid transition of urban areas towards energy efficiency and the adjustment to challenges created by climate change is highly required. It is also one of the major challenges for public authorities to reduce energy consumption and urban heat in cities without significant construction works. Therefore, public authorities, and in particular city planners and all urban actors willing to participate to the energy transitions, need to be equipped with simple but useful ICT tools, geospatial solution, strategies and methodologies for a proper energy monitoring and management to increase energy efficiency and renewable energy usage in urban spaces. Particularly in the building sector, energy consumptions and urban heat islands are influenced by the spatial organization. Accordingly, many different approaches and tools are developed for the spatial representation of energy demand, production, consumption and $\mathrm{CO} 2$ emissions reduction, such as a Geographical Information Systems (GIS) and LOD 3D city models. Geospatial tools hold great potential for boosting more energy efficient planning. In particular, they have proven their utility in assessing renewable energy potential, visualizing energy flows, understanding the spatial dimension of energy demand and consumption, quantify light pollution at night or district heating system within an urban scale, assess urban heat island, etc. (Agugiaro et al., 2012; Pipia et al., 2014; Resch et al., 2014; Voelkel and Shandas, 2017; Toschi et al., 2017). Indeed the implementation of spatial analysis using geospatial products can be very useful to manage, archive, analysis and visualize energy data, to optimize the energy sources available on the territory and better draw policies and efficient strategies (Ascione et al., 2013; Lombardi and Trossero, 2014; Agugiaro, 2016; Torabi et al., 2016).

\subsection{Aims and structure of the paper}

The aim of this paper is multifold: (i) to review existing methods and practices based on GIS and 3D city models to perform spatial analyses and understand energy efficiency solutions; (ii) to present two authors' on-going projects related to dynamic public lighting (Dynamic Light) and energy management in public buildings (BOOSTEE-CE); (iii) to draw some lesson learnt and perspectives for the increasing request of ICT tools for low carbon cities and to promote sustainable energy planning strategies. It shall be noted that the approach presented in this paper does not focus on the issue of spatial scale, but on methods and needs of low carbon cities in the field of integrating heterogeneous energy-related information and 3D city models with GIS environments.

This paper is structured as follows. Section 2 is dedicated to the related works in the scope of widespread utilization of energyrelated geospatial data towards the better quality of energy

\footnotetext{
* Corresponding author
} 
management and renewable energy usage in urban areas. Section 3 presents the fully operating webGIS solutions in order to improve urban energy efficiency and planning low carbon strategies. Then (Section 4-5) two authors' ongoing EU projects (Dynamic Light and BOOSTEE-CE) are presented. Although the projects are not yet completed, critical remarks emerged from the projects are discussed (Section 6), together with the indication of further activities.

\section{RELATED WORKS}

There are abundant interdisciplinary projects aiming to deploy ICT and geospatial solutions to (i) enhance knowledge and skills in the field of efficient energy management, (ii) reduce knowhow disparities among EU countries, (iii) increase capacities of the public sector and related entities for improving the energy efficiency of public infrastructures by means of geospatial data and (iv) widespread geoinformatics in the energy sector.

Among geospatial tools and solutions, GIS and 3D city models offer many benefits for capture, process, store and visualize energy-related data in urban environments, track consumptions and demands, assess rehabilitation conditions, etc. Many studies have been conducted to assess the potential for renewable energy production, measure energy consumption or improve the energy efficiency at urban scale. Biljecki et al. (2015) identified more than a hundred different applications for 3D city models, where among others indicated the urban energy sector and as a need energy demand estimation of households in order to assess the benefit of energy-efficient retrofitting. Previtali et al. (2014) noted the utility of 3D building models for thermal retrofit of the buildings and further energy efficiency evaluation. Thermal assessment coupled with 3D building models may indeed determine thermal bridges and heat losses. Based on the building typology and the additional energy-related data, Carrión (2010) describes a method to calculate energy consumption characteristic and thus it enables generalizing buildings into determined heating classes and as well quickly locate the particular buildings with the deviation to the estimated value. Nouvel et al. (2013) investigated the uncertainties in heating demand calculation with respect to geometric and thermal uncertainties. As geometric category, the building height, volume and window to façade ratios have been identified whereas the air change rate (i.e. a measure of the air volume added to or removed from a space divided by the volume of that space) was used as thermal category. Based on the outcomes, the energy saving potentials per particular buildings were mapped and, in the further steps, the refurbishment priorities were defined.

Many of studies have focused on assessing building roofs 3D geometries, derived using photogrammetry (Nex et al., 2013) or LiDAR data (Zheng et al., 2014; Martian et al., 2015) to install solar collectors or photovoltaic (PV) cells so to produce green energy (Amado and Poggi, 2014; Chaturvedi et al., 2017). If 3D building models are not reconstructed in detail, shading influences of nearby houses or roof components are not taken into consideration and so determined suitable roof areas for solar production might not meet the intended purpose (Strzalka et al., 2012; Alam et al., 2013).

Geospatial data and GIS tools are also used for public lighting infrastructures, e.g. determine different lighting scenarios, detect light pollution or performing street light energy audit without a visiting the site, plan street illumination, etc. The use of detailed light maps showing the quantity of light is nowadays an important policy instrument for developing cities with regard to developing sophisticated lighting strategies to decrease light pollution, improve the energy efficiency and increase safety. The badly spatial distribution and design of public lighting infrastructure in urban space might sorely influences environment, human activities and safety (Feng and Murray, 2017). On the other hand, several approaches were presented to assess and visualize the amount of artificial light radiation at urban scale (light pollution or skyglow). Satellite-based methods (e.g. https://www.lightpollutionmap.info) have very low resolution but they serve for overall views and understanding. Kyba et al. (2015) compares different remote sensing sources to image the Earth at night and derive upwelling radiance of cities. Hale et al. (2013) explored how artificial lighting vary with built density and land-use in Birmingham using aerial night photography. Pipia et al. (2014) produced luminance map using airborne imagery at very high resolution.

\section{PROJECTS AND BEST PRACTICES IN 3D URBAN ENERGY SYSTEMS}

Modelling in 3D urban energy systems requires the use, harmonization and integration of heterogeneous input data sources in order to (i) understand and visualize how energy flows, (ii) better manage and analyse energy data, (iii) optimize the available energy sources and (iv) implement necessary energy efficient measures. Urban 3D data were already used for research, development and application-oriented projects related to energy efficiency, energy audit, heat losses computation, PV estimation, etc. (Nex et al., 2013; Agugiaro, 2015; Biljecki et al. 2015; Wate and Coors, 2015; Hong et al., 2017). Among the international projects, it's worth to mention Step Up (www.stepupsmartcities.eu), SENECA (http://seneca.fbk.eu), SUNSHINE (www.sunshineproject.eu), etc. The following sections present two outstanding cases where geospatial technologies and ICT tools are effectively used to assist cities in understanding urban energy flows and potentials.

\subsection{The Energy and Climate Atlas - Helsinki, Finland}

The Helsinki Climate and Energy Atlas (https://kartta.hel.fi/3d/atlas) was realized using Helsinki semantic 3D city model (Fig. 1). The energy atlas of the city is part of the mySMARTLife project (https://mysmartlife.eu), in which Helsinki has compiled energy-related data on its building stock and made it freely available for public use. The designed application covers all energy-related topics, starting from fundamental building information, such as energy-efficiency upgrades, performance classifications or the energy sources used for heating, ending on sophisticated analyses and simulations in the scope of energy efficiency. The content of the Atlas (Fig. 1) has been organized in three thematic categories:

- basic building information: it includes use, height, number of floors, building materials, year of construction, etc.

- building energy and repair information: it includes heating mode, source of energy, airflow rate, energy certificates, energy efficiency index and category, etc.

- building consumption data: it includes consumption data for district heating, building electricity and water requests and consumptions, etc.

Solar irradiation estimation and PV potential for the entire city are also available and visualized on the semantic building models. The atlas shows suitable roof locations for solar panels and solar panel potential. The developed Energy and Climate Atlas serves as a modern city's toolkit to reach assumed climate goals, encourage a public community to act, for example, by harnessing solar energy and as well aids enterprises to recognize the proper places for investment in clean technology solutions. It is an important tool for city of Helsinki in order to reduce greenhouse gas emissions by $80 \%$ and become carbon neutral by 2035 (http://www.stadinilmasto.fi/en/). 

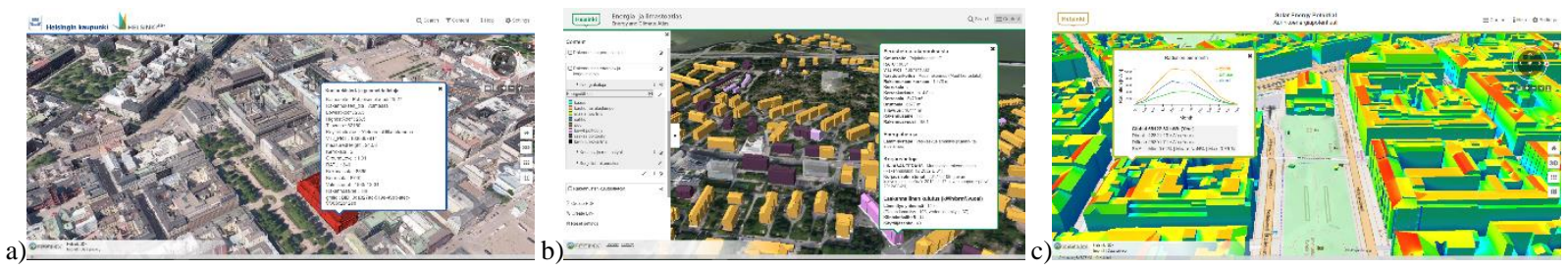

Figure 1: 3D buildings model with visible stored attributes as well as with building texture, build based on the CityGML standard (a - Helsinki 3D+ https://kartta.hel.fi/3d/); buildings categorized by energy source (b - The Climate and Energy Atlas: https://kartta.hel.fi//3d/atlas); solar irradiation analyses on the LOD2 building models (c - Helsinki solar energy potential: https://kartta.hel.fi/3d/solar/).

\subsection{The Energy Atlas - Berlin, Germany}

The Energy Atlas of Berlin (http://energyatlas.energie.tuberlin.de/en/) presents an integrated approach for strategic energy planning and use of renewable sources in urban areas (Krüger and Kolbe, 2012). It enables a representation of the actual state of building stock and their relevant energy data, and it supports the decision process by visualizing the effects of planned measures. The Energy Atlas is build based on the CityGML semantic 3D city model of Berlin. The 3D geometries provide itself a fundamental set of semantic information, such as building address, height, volumes and purpose. In order to increase their usefulness for energy management purposes, various methods and information from existing energy-related databases were incorporated into the $3 \mathrm{D}$ city model of Berlin:

- solar potential estimated for ca 500,000 Berlin's roof from the Solar Atlas Berlin. The dataset includes also additional information, such as: roof pitch, solar irradiation as well as average efficiency and price of solar cells (https://www.businesslocationcenter.de/wab/maps/solaratlas) - data and modeling approach for various utility network (i.e. gas, water, electricity, etc.) developed in the SIMKAS-3D project (Simkas3D, 2010)

- a methodology to perform assessment of the energetic rehabilitation of buildings and heating energy consumption (Carrión, 2010; Carrión et al., 2010).

With these energy-related data and models, the developed application can map energy consumptions, assess heating and electricity demands, present the energetic building characteristics and energy savings potential, design an optimal electricity network as well as present the possibilities of geothermal and solar energy potentials. Given the complexity of the city, the Berlin's Energy Atlas act as fundamental best practise and guidance tool in the scope of efficient energy planning and use of renewable energy sources.

\section{DYNAMIC PUBLIC LIGHTING}

The Dynamic Light project (Towards Dynamic, Intelligent and Energy Efficient Urban Lighting - http://www.interregcentral.eu/Dynamic-Light) focuses on public street lighting which plays a significant role in the urban environment and is an integral part of smart cities and city life. Public lights are normally poorly designed, not satisfying citizens' expectations and possibly causing hazards to human health and environmental effects. The negative impact of artificial outdoor lights (also known as "night light pollution") puts some pressure nowadays on local authorities to develop lighting strategies to decrease light pollution (preserving citizens' security) and, at the same time, improve the energy efficiency of street lighting infrastructure. Street lights in urban space operate in complex systems with a large amount of light points and related technical and operational data to manage. This presents a considerable challenge for public lighting managers. Using GIS tools and 3D building models, the spatial (i.e. location) and non-spatial (i.e. type of luminaire, lighting type, pole height, etc.) data of individual lighting points can be presented in an organized manner and analysed according to users' needs.

\subsection{Pilot areas}

The Dynamic Light workflow provides for the development of six geospatial databases management systems in order to (i) link spatial localization of lighting points with technical non-spatial information on lighting infrastructures and (ii) establish concepts which will bring energy-saving benefits and meet the expectations of user's according to their lighting social needs in the urban environment. The six project's pilot areas are: Municipality of Cesena and Mantova (Italy), Hanseatic City of Rostock, (Germany), Town of Čakovec (Croatia), Town of Sušice (Czech Republic), Municipality and Town of Lwówek Śląski (Poland). Altogether, more than 31,000 lighting points together with technical attributes within the selected pilot's areas have been recorded in the geodatabases and visualized within 3D GIS environments.

\subsection{Methodology}

City's streetlights operate as complex systems with large amount of light points and related technical and operational data to manage. The creation of urban street light inventory ("street light audit") in a GIS environment and the combination with 3D building models supports a better management of all existing components of a public lighting system and hence act as an important policy instrument at urban scale to develop sophisticated and modern lighting strategies towards low carbon cities. The street lighting inventory (Table 1) and geodatabase creation (Bakr et al., 2007 - Fig. 2a) is a pre-requisite step for changing, purchasing or upgrading any lighting system.

In order to create a GIS streetlight platform which would be a comprehensive tool for efficient streetlight management and design, we collected and stored data in the following categories: - geospatial information of urban areas;

- streetlight inventory data (localization of each luminaire, type of luminaire, lighting type, pole and mounting criteria, etc.);

- energy data of consumptions per each luminaire or lamp power; - photometric data for spill light and light pollution analysis.

Within the project activities, in case data were not available, the municipality performed some field surveys with smartphone applications to collect the necessary information (Fig. 2b). Such heterogeneous databases, combined with LOD1 building models (Fig. 3) and, in the future, with other street-level 3D models, allows to run analyses, simulations, visualizations and policy definitions. They will act as a modern support tool to plan retrofits to save energy and improve light quality (planning of public works and investments), to monitor the impact of the investments on the street lighting system and to help local authorities to improve its knowledge of the status quo of the lighting system. 
a)

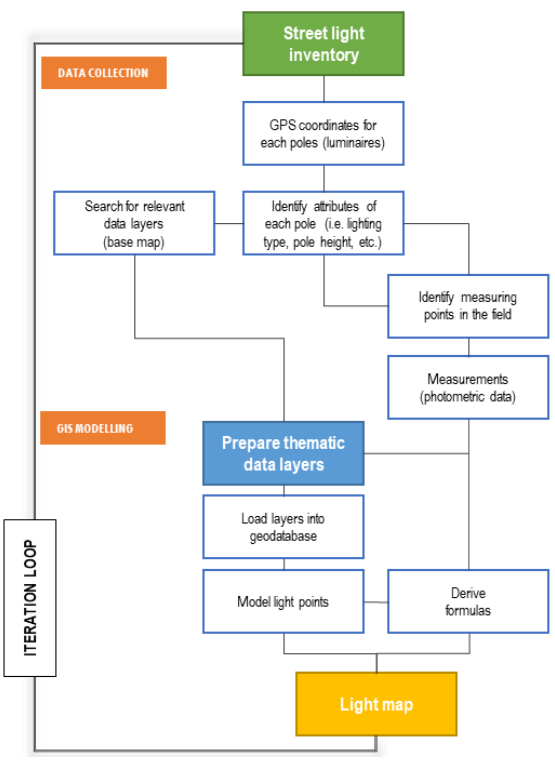

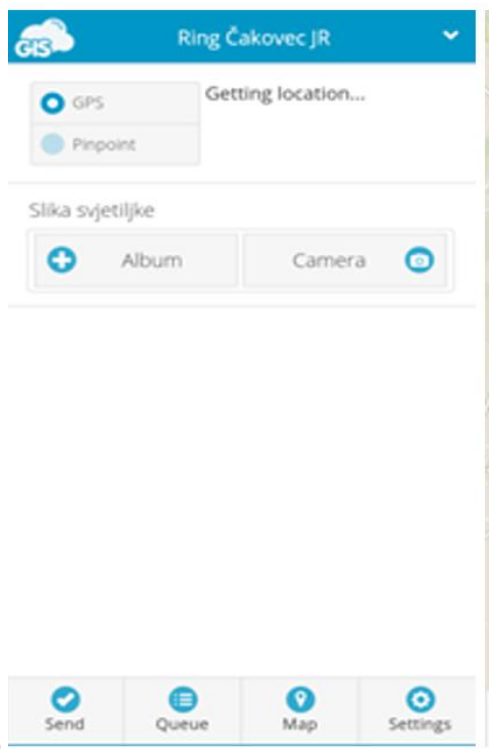

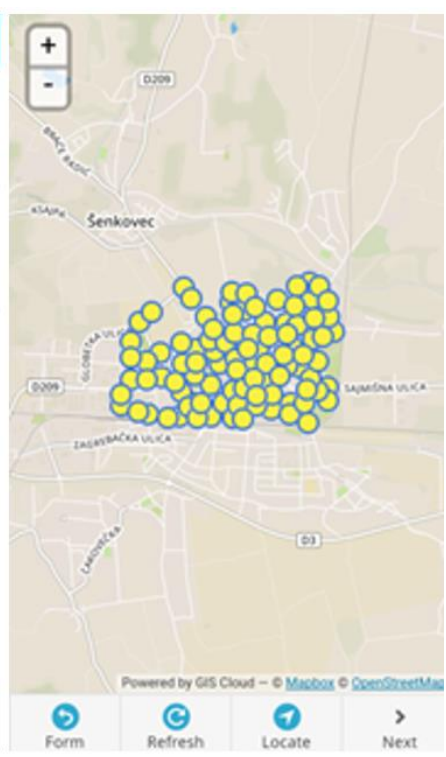

Figure 2: The methodology for street light inventory geospatial databases creation (a). GIS Cloud mobile application (https://www.giscloud.com) used in Čakovec (Croatia) to collect pole positions and light information (b).

Table 1. Data records in the Dynamic Light project databases.

\begin{tabular}{|c|c|c|}
\hline \multicolumn{2}{|c|}{ Description - attributes } & Unit \\
\hline \multirow{2}{*}{$\begin{array}{l}\text { Coordinates } \\
\text { of each pole } \\
\text { (GNSS) } \\
\end{array}$} & Coordinate X: latitude & deg \\
\hline & Coordinate Y: longitude & deg \\
\hline $\begin{array}{l}\text { Ownership } \\
\text { of each } \\
\text { luminaire }\end{array}$ & $\begin{array}{l}\text { The owner: Municipality, ESCO, } \\
\text { Private, Other }\end{array}$ & - \\
\hline $\begin{array}{l}\text { Maintenance } \\
\text { of each } \\
\text { luminaire }\end{array}$ & $\begin{array}{l}\text { The manager: Municipality, ESCO, } \\
\text { Private, Other }\end{array}$ & - \\
\hline \multirow[t]{5}{*}{$\begin{array}{l}\text { Luminaire } \\
\text { criteria }\end{array}$} & $\begin{array}{l}\text { The type of luminaire: } \\
\text { cobra-head, decorative acorn, } \\
\text { decorative teardrop, etc. }\end{array}$ & - \\
\hline & $\begin{array}{l}\text { Lighting type: } \\
\text { LED Street Light, Low P Sodium, } \\
\text { High Pressure Mercury, High } \\
\text { Pressure Sodium, Low P Mercury (C) } \\
\text { Single, etc. }\end{array}$ & - \\
\hline & Lamp power [Wattage] & $\mathrm{W}$ \\
\hline & $\begin{array}{l}\text { Energy consumption per each } \\
\text { luminaire }\end{array}$ & $\mathrm{kWh}$ \\
\hline & $\begin{array}{l}\text { Lighting controls: photocell, timer, } \\
\text { etc. }\end{array}$ & - \\
\hline \multirow{5}{*}{$\begin{array}{l}\text { Photometric } \\
\text { data }\end{array}$} & Luminous intensity (l) & $\mathrm{cd}$ \\
\hline & Illuminance E - Lux & $1 \mathrm{~m} / \mathrm{m}^{2}$ \\
\hline & Luminance L & $\mathrm{cd} / \mathrm{m}^{2}$ \\
\hline & Date of measurement & - \\
\hline & Time of measurement & - \\
\hline \multirow[t]{8}{*}{$\begin{array}{l}\text { Pole and } \\
\text { mounting } \\
\text { criteria }\end{array}$} & $\begin{array}{l}\text { The condition of the asset: } \\
\text { Excellent, Very Good, Good, Fair, } \\
\text { Poor, Very Poor, Unknown }\end{array}$ & - \\
\hline & The date the asset was installed & - \\
\hline & The date the asset was renovated & - \\
\hline & $\begin{array}{l}\text { Height of street lighting column (pole } \\
\text { height) }\end{array}$ & $\mathrm{m}$ \\
\hline & The arm length of the light pole & $\mathrm{m}$ \\
\hline & Fixtures per pole & \\
\hline & Distance between poles & $\mathrm{m}$ \\
\hline & Lighting obstructions & - \\
\hline
\end{tabular}
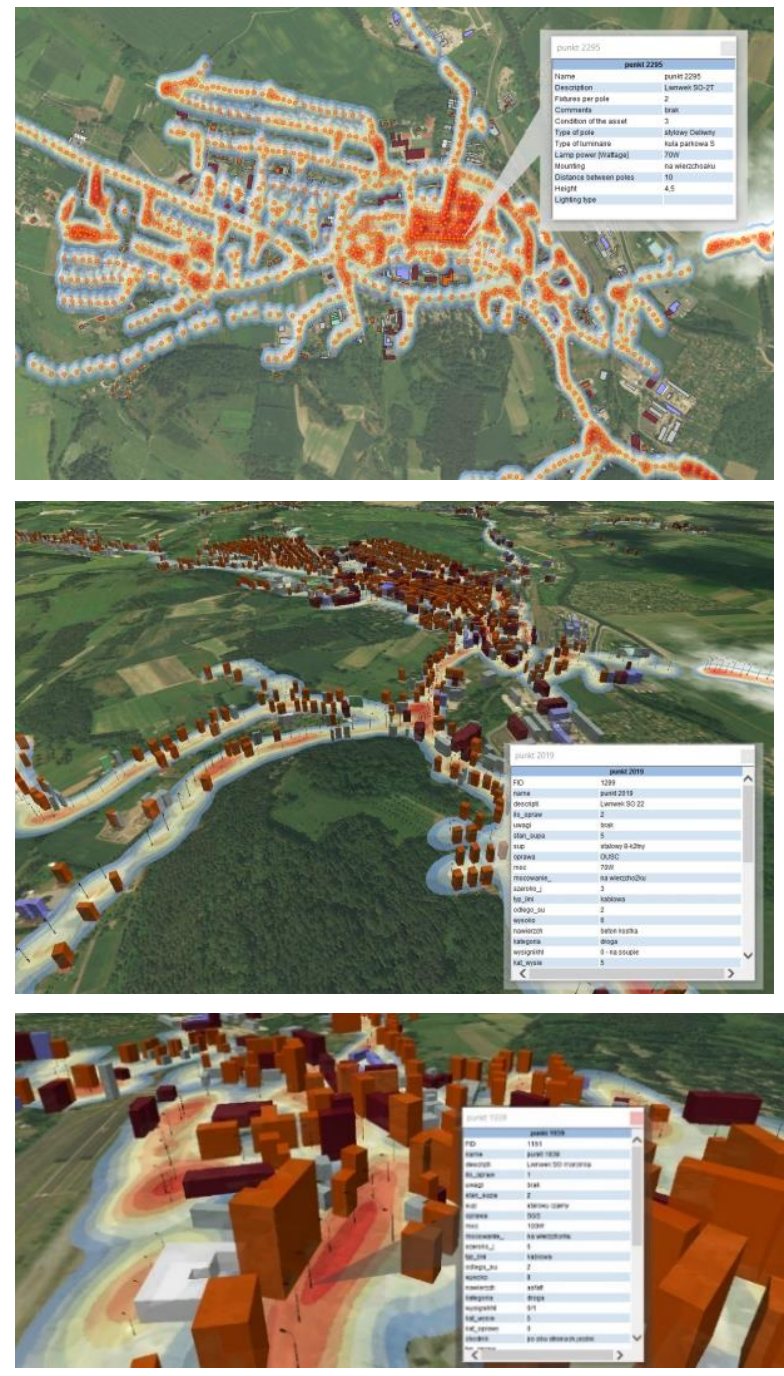

Figure 3. Example of a 2D and 3D access and visualization of the developed geodatabase for storing, querying and visualizing information of the street lighting inventory together with building models (LOD1) for the Municipality and Town of Lwówek Śląski (Poland). 


\section{ENERGY MANAGEMENT IN PUBLIC BUILDINGS}

The BOOSTEE-CE project (Boosting energy efficiency in Central European cities through smart energy management http://www.interreg-central.eu/BOOSTEE-CE) aims to support the local authorities in playing an exemplary role in undertaking actions to improve the energy performance of public buildings. Public buildings are infrastructures where the greatest progress can be made towards energy efficiency transformation in urban environments but to boost this process different energy planning domains (i.e. estimation of energy consumption, solar potential estimation, heat emissions, etc.) have to be tackled. This requires a holistic approach and the combination of extensive and complex, spatial (cadastral footprints, LiDAR, 3D building models, etc.) and non-spatial (i.e. cadastral information, energy demand, technical data, etc.) information on public buildings, which may be found in many different offices and encoded in different databases. Spatial energy management and accurate monitoring of energy flows in public infrastructures might support the local authorities in boosting energy efficient actions in the city, increases public awareness through open access to the energy consumption data and ultimately reducing energy consumption and $\mathrm{CO} 2$ emissions. But the collection, harmonization and utilization of energy-related information to support energy transition in public buildings still presents a considerable challenge for cities and local administrations. Within the BOOSTEE-CE project, a 3D energy management tool (3DEMS) is under development to serve as seedbed for implementation of energy efficient measures in the project's pilot areas. The tool will (i) show the practicality use of geospatial data and 3D building models for energy-related needs, (ii) improve energy efficiency planning and management, (iii) facilitate renewable energy usage and (iv) help in defining Sustainable Energy Action Plans (SEAP) at urban level. The challenges of the project are:

- the selection of useful information that 3DEMS should provide to offer an added value for energy managers and policy makers in daily operations and to improve spatial decision making;

- the smart integration and deployment of already existing information located in different repositories, instead of development of another data layers;

- the definition of correct levels of detail that makes the provided or produced information more appropriate for a defined scale;

- the assessment of solar energy potentials and heating loses of public buildings roofs;

- the definition of refurbishment priorities and planning of successive actions that will lead to decreased energy consumption.

\subsection{Pilot areas}

The workflow developed within the BOOSTEE-CE project is deployed to 8 pilot areas: Emilia Romagna region (Italy), Judenburg-Lindfeld municipality (Austria), Zlin region (Czech Republic), Tolna municipality (Hungary), Plonsk municipality (Poland), Koprivnica municipality (Croatia), Velenje municipality (Slovenia) and Poland / Czech Republic crossborder region. In these areas, for selected public buildings, geospatial databases with urban and energy data are created in order to combine them with 3D building geometries within the 3DEMS project tool.

\subsection{Methodology}

The BOOSTEE-CE project will provide for a robust and smart tool (3DEMS) based on heterogeneous databases (Table 2) and
3D building models (LOD1 and LOD2 - the latter only for some pilot buildings) in order to allow local authorities to boost energy efficient actions in cities. Considering the goals of the project, the heterogeneous data about energy and buildings (spatial and nonspatial data) in pilot areas (PA) include:

- building footprints with/without attribute information (such as number of floors, building height, etc.)

- maps (2D vector or raster products) representing, at a certain scale, city elements such as buildings, roads, parks, communication lines, etc. They can also have energy-related information related e.g. to photovoltaic (PV) potential of building roofs (solar maps);

point clouds acquired with LiDAR flights or generated with photogrammetric flights, from where buildings heights and roof shapes could be inferred

- Digital Elevation Model (DEM) of the surrounding environment for the PV potential estimation;

- aerial visible images from which point clouds, orthoimages, 3D buildings or maps can be produced;

- thermal images acquired with thermal cameras to document the heating loses of e.g. building facades or roofs;

- other information such as construction plans, energy audit certificates, energy bills.

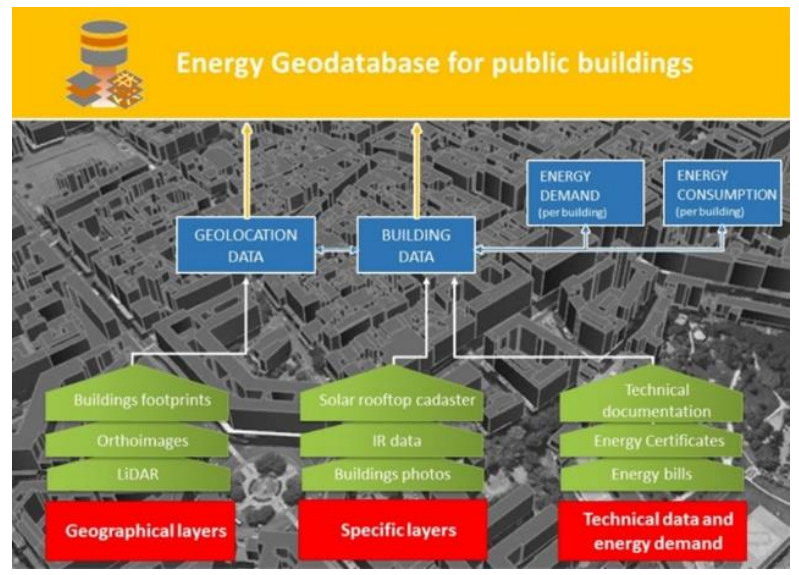

Figure 4. The BOOSTEE-CE strategy to create geospatial databases of energy information for public buildings.

As none of the pilot areas of the project have 3D city/building models available and new data acquisitions were not feasible, 3D building geometries were generated with the available geospatial data (maps and very low-resolution point clouds). This process was divided into data harmonization - to obtain interoperable geodatabases and generation of 3D geometries, based on the available geodata (Wahl et al. 2008; Over et al., 2010; Ledoux et al., 2011; Goetz, 2013; Toschi et al., 2017): extrusion of building footprints with attribute information (LOD1) and fitting geometric primitives on dense point clouds (LOD2).

Starting from these data, the 3DEMS webGIS tool (Fig.6) allows users to interactively navigate a map (LOD0) or 3D building models (LOD1-2) of an urban environment, select a building of interest and retrieve energy and other cadastral/building information, including non-spatial data (Table 2). Query functions over the same area are also possible in order to visualize aggregation results and allow better analyses, simulations, etc. (Fig. 7-8). For example, the energy-related data available at building level are important e.g. to help the realization, implementation and monitoring of Sustainable Energy Action Plan (SEAP) at city level and the transition towards smart cities. 

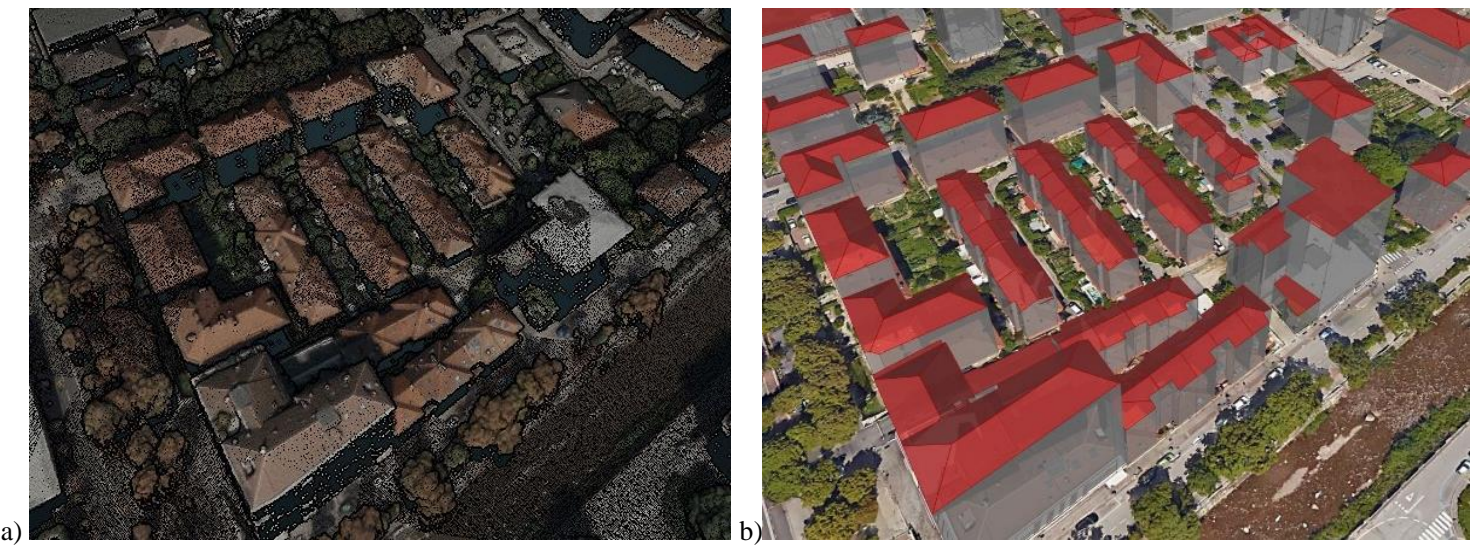

Figure 5. A dense point cloud over an urban area (a) and fitting of geometric primitives to produce LOD2 building models (b).

Table 2. Data records in project databases linked to the 3D geometries queryable in 3DEMS

\begin{tabular}{lll}
\hline \multicolumn{1}{c}{ Field } & Units & \multicolumn{1}{c}{ Description } \\
\hline Official name & - & \multicolumn{1}{c}{-} \\
\hline Year of construction & - & \multicolumn{1}{c}{-} \\
\hline Building type & - & $\begin{array}{l}\text { Type of building: residential, } \\
\text { agricultural, civil, medical, } \\
\text { educational, government, } \\
\text { industrial, military, religious, } \\
\text { transport. }\end{array}$ \\
\hline $\begin{array}{l}\text { Typology (number of } \\
\text { floors) }\end{array}$ & - & - \\
\hline $\begin{array}{l}\text { Energy source type } \\
\text { (heat) }\end{array}$ & - & $\begin{array}{l}\text { Type of the heat source: } \\
\text { geothermal energy, district } \\
\text { heating, cogeneration unit, } \\
\text { heat pump, biofuel boilers, } \\
\text { solid fuel, electricity, natural } \\
\text { gas, oil. }\end{array}$ \\
\hline Energy audit & - &
\end{tabular}

\begin{tabular}{|c|c|c|}
\hline $\begin{array}{l}\text { Energy consumption } \\
\text { (heating) }\end{array}$ & GJ/year & - \\
\hline $\begin{array}{l}\text { Electricity } \\
\text { consumption }\end{array}$ & kWh/year & - \\
\hline $\begin{array}{l}\text { The specific CO2 } \\
\text { emissions }\end{array}$ & tons/year & - \\
\hline $\begin{array}{l}\text { The total CO2 } \\
\text { emissions }\end{array}$ & tons/year & - \\
\hline $\begin{array}{l}\text { Technology used to } \\
\text { harvest a renewable } \\
\text { energy source }\end{array}$ & - & $\begin{array}{l}\text { Type of the technology: } \\
\text { photovoltaics (PV), solar } \\
\text { collectors, biofuel boilers, } \\
\text { heat pumps }\end{array}$ \\
\hline $\begin{array}{l}\text { Estimated } \\
\text { photovoltaic } \\
\text { potential of roof }\end{array}$ & $\mathrm{kW}$ & $\begin{array}{l}\text { Calculated from the solar } \\
\text { potential maps }\end{array}$ \\
\hline $\begin{array}{l}\text { EE measures already } \\
\text { implemented in the } \\
\text { building }\end{array}$ & - & \multirow{2}{*}{$\begin{array}{l}\text { Type of the measures: (i) } \\
\text { reducing heating demand: } \\
\text { improving the insulation, } \\
\text { limiting the exposed surface } \\
\text { area, reducing ventilation } \\
\text { losses, selecting efficient } \\
\text { heating system, new roof; (ii) } \\
\text { reducing cooling demand, } \\
\text { (iii) reducing energy use for } \\
\text { lighting, (iv) reducing energy } \\
\text { used for heating water, etc. }\end{array}$} \\
\hline $\begin{array}{l}\text { Recommended EE } \\
\text { measures for the } \\
\text { building }\end{array}$ & - & \\
\hline $\begin{array}{l}\text { Estimation of the } \\
\text { amount of heating } \\
\text { losses }\end{array}$ & MWh/year & - \\
\hline
\end{tabular}
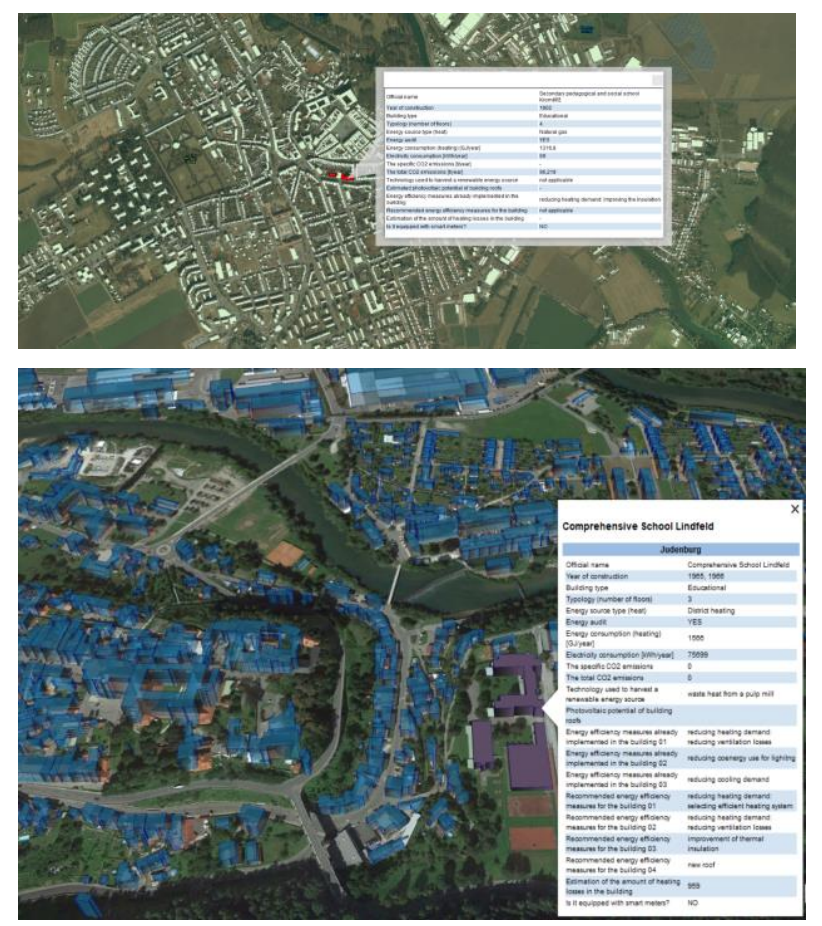

Figure 6: Web-based visualization (based on Cesium https://cesiumjs.org/) of building information (LOD0 and LOD1) for Zlín Region, Czech Republic (top) and Municipality of Judenburg, Austria (bottom) with associated energy database.

\section{CONCLUSIONS}

Nowadays, urbanized areas have a high potential in the deployment of local and regional energy systems based on renewable energy utilization and energy maintenance, but it is important to trigger bottom-up initiatives to improve energy efficiency approaches. A rapid transition of urban areas towards energy efficiency and the adaption to challenges created by climate change is highly required. Powerful solutions and tools are provided by ICT methods and geospatial data.

The paper presented various existing 3D webGIS solutions dedicated to public authorities - as well as citizen - to better manage and analyse energy data, implement effective energy efficiency strategies e.g. for retrofitting existing buildings and managing energy use in public lighting infrastructure.

In developing webGIS solutions, the availability of reliable and accurate geospatial data plays an important role given the constantly growing amount of heterogeneous data sources which are generally established at different times, based on different 

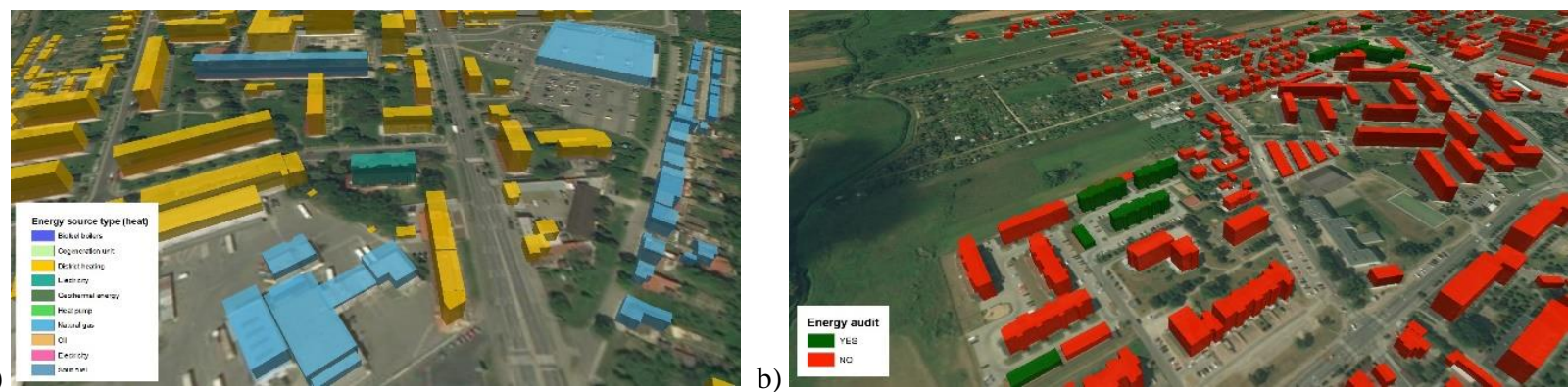

Figure 7: Visualization of queries and aggregations: energy sources used for buildings heating (a) and buildings with energy audit certificates (b).

platforms, having different licenses or produced to fit different industries or departments, varies from country to country. In the reported ongoing projects, the utilization of geospatial data in favour of the urban energy sector as shown great potential. In both projects, collected and subsequently harmonized data are being used for visualization and query purposes (e.g. present data in a sophisticated way through performed analysis, display energy consumptions or flows, etc.) as well as to compute light pollution / street light density, photovoltaic (PV) potential of building roofs and connected with it costs, etc. All these analyses can facilitate policy makers and the realization of energy plans. Although the presented projects are not yet completed, for the time being, critical remarks emerged: (i) geospatial data update, heterogeneity and availability is an obstacle, in particular when working in middle/low-size urban areas; (ii) the effort of producing LOD2-3 building models is often not paid back as user needs can be satisfied with LOD1 models; (iii) 3D visualization tools are often seen as something esthetically nice but not really useful for policy makers. There will need some more years to have 3D city models as a de-facto tool for such applications but the initial results and prospective are very positive and encouraging.
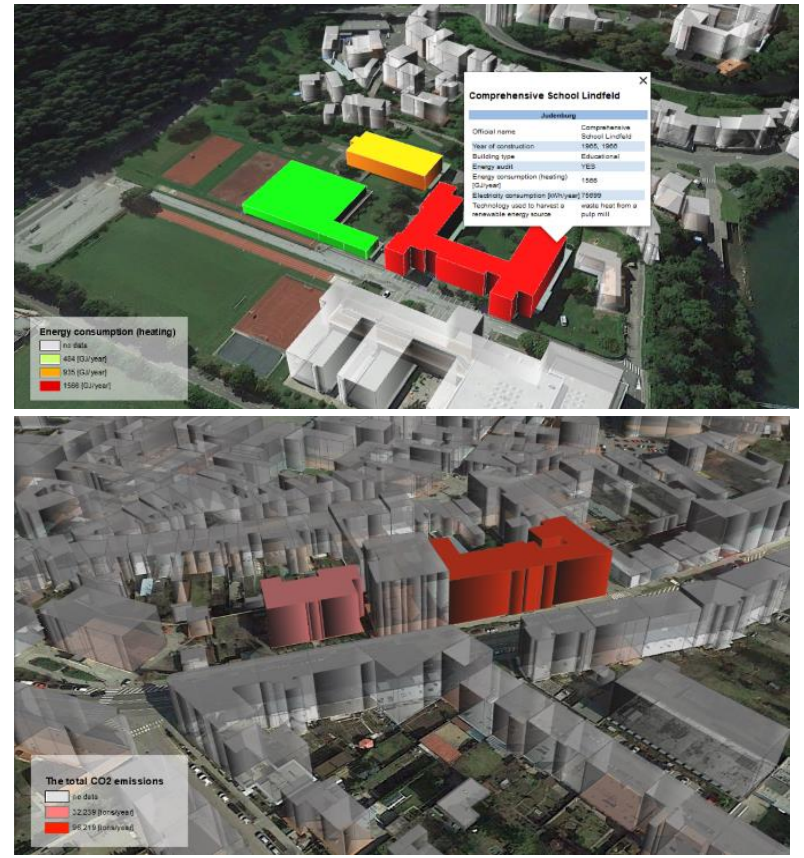

Figure 8: Pilot buildings in Judenburg, Austria, shown according to their energy consumption (above) and pilot buildings in Zlin, Czech Republic, shown according to the emitted $\mathrm{CO} 2$ (below).

\section{ACKNOWLEDGEMENTS}

The Dynamic Light and BOOSTEE-CE projects are EU-funded projects implemented through the INTERREG CENTRAL EUROPE Programme and co-financed by the European Regional Development Fund. (ERDF). Authors are thankful to all projects partners for their contributions in the projects activities.

\section{REFERENCES}

Agugiaro, G., Nex, F., Remondino, F., De Filippi, R., Droghetti, S., Furlanello, C., 2012: Solar radiation estimation on building roofs and web-based solar cadastre. ISPRS Ann. Photogramm. Remote Sens. Spatial Inf. Sci., Vol. I(2), pp. 177-182

Agugiaro, G., 2015: Energy planning tools and CityGML-based 3D virtual city models: experiences from Trento (Italy). Applied Geomatics, Vol. 8(1), pp 41-56

Agugiaro, G., 2016: First steps towards an integrated CityGMLbased 3D model of Vienna. ISPRS Ann. Photogramm. Remote Sens. Spatial Inf. Sci., Vol. III-4, pp. 139-146

Alam N., Coors V., Zlatanova S., 2013: Detecting shadow for direct radiation using CityGML models for photovoltaic potentiality analysis. Proc. Urban and Regional Data Management Symposium (UDMS), pp. 191-196

Amado, M., Poggi, F., 2014: Solar urban planning: a parametric approach. Energy Procedia, Vol. 48, pp. 1539-1548

Ascione F., Francesca De Masi R., De Rossi F., Fistola R., Sasso, M., 2013: Analysis and diagnosis of the energy performance of buildings and districts: Methodology, validation and development of Urban Energy Maps. Cities, pp. 270-283

Bakr, A.F., I. Diab, Saadallah, D., 2007: Detecting Inefficient Lighting Solutions: Step-by-Step Geographic information system (GIS) Technique. Proc. $3^{\text {rd }}$ Int. Conf. of the Arab Society for Computer Aided Architectural Design, pp. 491-504

Biljecki, F., Stoter, J., Ledoux, H., Zlatanova, S., Çöltekin, A., 2015: Applications of 3D city models: State of the art review. ISPRS Int. J. Geo-Inf., Vol. 4, 2842-2889

Butt, M.J., 2012: Estimation of light pollution using satellite remote sensing and geographic information system techniques. GIScience \& Remote Sensing, Vol. 49(4)

Carrión, D., 2010: Estimation of the energetic rehabilitation state of buildings for the city of Berlin using a 3D city model represented in CityGML. Master Thesis, Technische Universität Berlin, Germany

Carrión, D., Lorenz, A., Kolbe, T.H., 2010: Estimation of the energetic rehabilitation state of buildings for the city of Berlin using a $3 \mathrm{D}$ city model represented in CityGML. ISPRS Int. 
Archives of Photogramm. Remote Sens. \& Spatial Inf. Sci., Vol. 38(4/W15), pp. 31-36

Chaturvedi, K., Willenborg, B., Sindram, M., Kolbe, T. H., 2017: Solar potential analysis and integration of the time-dependent simulation results for semantic 3D city models using dynamizers. ISPRS Ann. Photogramm. Remote Sens. Spatial Inf. Sci., IV4/W5, pp. 25-32

Directive 2012/27/EU of the European parliament and of the council of 25 October 2012 on energy efficiency, amending Directives 2009/125/EC and 2010/30/EU and repealing Directives 2004/8/EC and 2006/32/EC, Official Journal of the European Union L 315/1, 14.11.2012, available at: http://eurlex.europa.eu/ (last access: July $15^{\text {th }}, 2018$ )

Feng, X., Murray, A.T., 2017: Spatial analytics for enhancing street light coverage of public spaces. LEUKOS - Journal of Illuminating Engineering Society of North America, Vol. 14, pp. $13-23$

Gago, E.J., Roldan, J., Pacheco-Torres, R., Ordóñez, J., 2013: The city and urban heat islands: A review of strategies to mitigate adverse effects. Renewable and Sustainable Energy Reviews, Vol. 25, pp. 749-758

Goetz, M., 2013: Towards generating highly detailed 3D CityGML models from OpenStreetMap. Int. Journal of Geographical Information Science, Vol. 27, pp. 845-865

Hale, J. D. Hale J.D., Davies, G., Fairbrass, A.J., Matthews, T.J., Rogers, C.D., Sadler, J.P., 2013: Mapping Lightscapes: spatial patterning of artificial lighting in an urban landscape. PLOS ONE, 8(5), p. e61460

Hong, T., Chen, Y., Piette, M.A., 2017: Automatic generation and simulation of urban building energy models based on city datasets for city-scale building retrofit analysis. Energy Technologies Area

Krüger, T., Kolbe, T.H., 2012: Building analysis for urban energy planning using key indicators on virtual 3D city modelsthe energy atlas of Berlin. ISPRS Int. Archives of Photogramm. Remote Sens. \& Spatial Inf. Sci., Vol. 39(B2), pp. 145-150

Kyba, C.C.M., Garz, S., Kuechly, H., Sánchez de Miguel, A., Zamorano, J., Fischer, J., Hölker, F., 2015: High-Resolution imagery of Earth at night: new sources, opportunities and challenges. Remote Sensing, Vol. 7, pp. 1-23

Ledoux, H., Meijers, M., 2011: Topologically consistent 3D city models obtained by extrusion. Int. Journal of Geographical Information Science, Vol. 25, pp. 557-574

Lobão, J.A., Devezas, T., Catalão, J.P.S, 2015: Energy efficiency of lighting installations: software application and experimental validation. Energy Rep., Vol. 1, pp. 110-115

Lombardi P. and Trossero E., 2014: Beyond energy efficiency in evaluating sustainable development in planning and the built environment. Int. Journal of Sustainable Building Technology and Urban Development. 2014, pp. 274-282

Martín, A. M., Domínguez, J., Amador, J., 2015: Applying LIDAR datasets and GIS based model to evaluate solar potential over roofs: a review. AIMS Energy, Vol. 3(3), pp. 326-343

Nex, F., Remondino, F., Agugiaro, G., De Filippi, R., Poletti, M., Furlanello, C., Menegon, S., Dallago, G., Fontanari, S., 2013: 3D SolarWeb: a solar cadaster in the Italian alpine landscape. ISPRS Int. Archives of Photogramm. Remote Sens. \& Spatial Inf. Sci., Vol. 40(7/W2), pp. 173-178
Nouvel, R, Schulte C, Eicker U, Pietruschka, D, Coors, V, 2013: CityGML-based 3D City Model for energy diagnostics and urban energy policy support. Proc. IBPSA World

Over, M., Schilling, A., Neubauer, S., Zipf, A., 2010: Generating web-based 3D City Models from OpenStreetMap: The current situation in Germany. Computers, Environment and Urban Systems, Vol. 34, pp. 496-507

Pipia, L., Alamus, R., Tardà, A., Pérez, F., Palà, V., Corbera, J., 2014: A Methodology for luminance map retrieval using airborne hyperspectral and photogrammetric data. Proc. SPIE, Vol. 9245

Previtali, M., Barazzetti, L., Brumana, R., Cuca, B., Oreni, D., Roncoroni, F., Scaioni, M., 2014: Automatic façade modelling using point cloud data for energy-efficient retrofitting. Applied Geomatics, Vol. 6, pp. 95-113

Resch, B., Sagl, G., Törnros, T., Bachmaier, A., Eggers, J.-B., Herkel, S., Narmsara, S., Gündra, H., 2014: GIS-Based Planning and Modeling for Renewable Energy: Challenges and Future Research Avenues. ISPRS Int. J. Geo-Inf., Vol. 3, pp. 662-692

Ruparathna, R., Hewage, K., Sadiq, R., 2016: Improving the energy efficiency of the existing building stock: A critical review of commercial and institutional buildings. Renewable and Sustainable Energy Reviews, Vol. 53, pp. 1032-1045

Skarbal, B., Peters-Anders, J., Faizan Malik, A., Agugiaro, G., 2017: How to pinpoint energy-inefficient buildings? An approach based on the 3D city model of Vienna. ISPRS Ann. Photogramm. Remote Sens. Spatial Inf. Sci., Vol. IV-4/W3, pp. $71-78$

Strzalka A., Alam N., Duminil E., Coors V., Eicker, U., 2012: Large scale integration of photovoltaics in cities. Appl Energ., Vol. 93, pp. 413-421

Torabi, S., Lombardi, P., Mutani, G., 2016: GIS-based energy consumption model at the urban scale for the building stock. Proc. 9th IEECB\&SC Conference

Simkas3D: Simulation of Cascading Effects in the Failure of Utility Infrastructures, 2010: https://www.tuberlin.de/ztg/menue/projekte_und_kompetenzen/projekte_abges chlossen/simkas_3d/ (last access: July $\left.15^{\text {th }}, 2018\right)$

Toschi, I., Nocerino, E., Remondino, F., Revolti, A., Soria, G., Piffer, S., 2017: Geospatial data processing for 3D city model generation, management and visualization. ISPRS Int. Archives of Photogramm. Remote Sens. \& Spatial Inf. Sci., Vol. XLII-1W1, pp. 527-534

Voelkel, J., Shandas, V., 2017: Towards systematic prediction of urban heat islands: grounding measurements, assessing modeling techniques. Climate, Vol. 5(2)

Wahl, R., Schnabel, R., Klein, R., 2008: From detailed digital surface models to city models using constrained simplification. Photogrammetrie, Fernerkundung, Geoinformation (PFG), Vol. 3, pp. 207-215

Wate, P., Coors, V., 2015: 3D data models for urban energy simulation. Energy Procedia, Vol. 78, pp. 3372-3377

Zheng, Y., Weng, Q., 2014: Assessing solar potential of commercial and residential buildings in Indianapolis using LiDAR and GIS modelling. Proc. 3rd Int. Workshop on Earth Observation and Remote Sensing Applications (EORSA), pp. 398-402 